\title{
MEDIA BOUND CULTURE OF WOMEN'S IDENTITY AND DESIRE
}

\author{
HARASANKAR ADHIKARI \\ Monihar Co-operative Housing Society, \\ Flat No.-7/2, 1050/2, Survey Park, Kolkata-75, India \\ jaoya123@yahoo.co.in
}

\begin{abstract}
The post global era is signified in terms of women's changed status in the patriarchal society of India. Their participation in the work force is not experienced as good or as desired because they have to face rampant violence related to their reorganized desires. The media-bound culture is a prime cause of their mimetic behavior in lifestyle and other choices. This paper attempts to raise two questions: Might this be the major cause of the violence? Is there a relationship between consumerism and women's body as sex commodity?
\end{abstract}

Keywords: consumerism, media-bound culture, violence, women's changing status.

\section{Introduction}

In the post global era, the working women of India are experiencing change and this has the causal effect of violence against women in relation 
to their reorganised desires - occupation, clothing, freedom of movement and self-identification, etc (Niranjana and Vasudevan 2016).

But there is a huge impact of the media on women's changing desires that might be considered a media-bound culture. Young women in particular are imitating this media gazing lifestyle and making these life choices.

Women's participation in large-scale social production can facilitate their empowerment and equity in a patriarchal society (Angels 1948). Their meaningful employment (paid) and education are strategically significant in enhancing their social standing and role in the household and in society (Sen 1999) because working outside the home minimises their role as housekeepers. Thus, it allows them a freedom in certain areas which was not available to them earlier, i.e. personal decision-making in selecting a marital partner and participation in the decision-making process in the family and at the workplace, ability to handle finances according to their own wishes, political empowerment, etc. There is a gradual change taking place in women's private and public lives. But we also see that physical and sexual violence are rampant in Indian society. Are women becoming trapped in a new way within the realm of male domination due to their involvement in male gazing fields (Geetha 2002)? Might this be the prime cause of the violence? Is there a relationship between consumerism and women's body as sex commodity?

\section{Women's body and the media}

We are experiencing globalisation as a driving force in making available goods and services that were previously out of reach in developing countries like India, and this is the cause of the global cultural bound 
syndrome in this era of consumerism. It gives birth to a "consumer class" with the lifestyle and life choices of people changing irrespective of their age and gender (National Geographic News 2013).

The advertisement and entertainment industries (print, electronic/tele-media in different forms) play a role in forming a consumer's self-identity (Smith 1982). The problem with consumerism is that it makes the pursuit of happiness more difficult. The goal of consumerism is to keep the consumer wanting to purchase more goods. Nowadays, consumption is a way of life (Banks 1992). 'Women's bodies are not being escaped from it. Images of female body are largely promoting consumption of fashion, appliances, food, travel or cosmetics. It also influences the women/girls to step in the glamour world because they would earn name, fame and money easily to meet their needs and demands in present consumers' world. Women's body is used either to promote consumerism or to be consumed. The female form is presented as a commodity. It is depersonalized and presented only to signify consumption or as consumable commodity. In essence, body is socially constructed as commodity. Its presentation is in such a way as to include desire. The commodification co-opts the female body from the social subjects to whom it belonged, strips it of any subjectivity, and presents it as an object, as the signifier of consumption' (Clammer 1995). The relationship between consumption and the commodified female body in India is derided. 'Commodities from cars to cokes, shoe polish to nail polish display with young women close by signaling availability and sexuality. The sexuality of women's bodies becomes split off and reattached to a whole host of commodities reflective of a consumer culture. Cars, cokes, etc become a form of sexuality, a means of access to one's own and/or another's body' (Orbach 2005). 
Young women's bodies are exploited by the media as consumable signs of consumption; their sexuality becomes inseparably bonded to consumer items. The use value of the female body is subordinated to its exchange value. It is an important advertising tool. The system of business is based on commodification of the human being, on a mission to commodify "everything and everyone" (Clammer 1995). Here, 'limerence' - an emotional state of being in love and a desire for more than sex, a desire in which the sexual act may represent the greatest happiness - is attached to women as above. Since this mentality promotes love as "a beautiful experience" - the support and companionship of a member of the opposite sex are a very important aspect. We see that any product that promises the limerent man or woman a better likelihood of achieving limerent aims has an enormous market. Items and services that attract people to beautify themselves are in potential demand. The business of cosmetics, shampoos and hair colouring, diets, exercise programmes, clothing and other consumer items, including gifts to limerent objects books, jewellery, flowers and so forth' (Tennov 1979)

Catherine Hakim (2010) refers to women's body and images as erotic capital in her 'theory of erotic capital'. Sex appeal, beauty, and physical and social attractiveness that increase a man or woman's popularity with all members of his or her society, particularly with the opposite sex, are the components of erotic capital. Hakim lists the various elements that comprise erotic capital, including sexual attractiveness, social skills and liveliness. Some behaviours enabled by one's sexual attractiveness, for instance, may prove to be ownership-relevant insofar as they facilitate or secure the economic realisation of one's labour power, e.g. help in getting a lucrative job or a pay hike, etc. Thus, it is common to see in public spaces 
erotic pictures of the female body as a commodified product (Bordo 1999; Dotson 1999). The woman's aim is to sell herself successfully on the market. Her body, her mind, and her soul are her capital (Fromm 1955)

Max Weber spoke of "society based on knowledge", i.e. science, but there may coexist simultaneously a plethora of deeply irrational phenomena, such as a range of cults: beauty, body, and youth. Of course, these are not spontaneous creations - the whole industry operates through a variety of media to impose a commodified image of the female body, which engenders an obsession with attaining that "ideal" female face (Geetha 2002). The commodified female body is deemed incomplete unless she or rather her face is "painted" with makeup and the body adorned with the "right" clothes, shoes, and accessories, such as bags. Beauty and fashion products are marketed to make a woman believe that whatever they are selling will enhance her looks and make her feel better about herself (Geetha 2002).

\section{Women and employment}

However, women's employment status is increasing statistically. This may be a result of the changing dynamics of feminist consciousness and women's education. In some sectors of employment, women are becoming a part of work culture because female sexualization is an integral part of work-based relations. We have a description of historical sex-typing of jobs in Bradley's (1989) study, and Stanko (1988) argues that women's occupations are habitually sexualized, while Gherardi (1995) explains how conventional feminised jobs demand sexual skills and labour. We find this to be the case with women's work in the hotel and leisure industry, where female attractiveness is mentioned as a criterion of eligibility in the job description and specific uniforms and appearance are an intrinsic part of job 
recruitment, selection and continued employment. Researchers have also reported similar findings in a retail company (Adkins 1995; Cockburn 1991). Some other studies of various labour markets have noted a similar process of the exploitation of female sexuality for profit (Benet 1972; Pringle 1988). Their jobs were in the following areas: secretaries, waitresses (Crang 1994; Fine 1996; Hall 1993; Spradley and Mann 1975), beauty care professionals (Sharma and Black 2002; Oerton and Phoenix 2001; O’Toole 2003; Furman 1997; Gimblin 1996), air hostesses (Hochschild 1983; Tyler and Abbott 1998), newsreaders and booksellers (Woolf 1990), nursing and other 'caring' professions (James 1989; O’Brien 1994; Treweek 1996), female professionals (McDowell 1997; Rees 1992). The above studies have reflected on how the commodification of the female body is reproduced in workplace relations, especially in the service and care economy. Women's body is used as an integral part of various offers. In the present global context, in which personal relationships have been restructured in terms of emotional needs (Giddens 1992), sexuality is defined as a cultural product and practice which determines the structure of economic relations in official modes of production.

\section{Conclusion}

Today we live in a media gazing society. Furthermore, the media is mainly a male gazing profession. The global situation is changing the definition/parameters of happiness and satisfaction in our daily lives. The media and advertisements direct our choices and style of life from good morning to good night. The world is becoming a stage for competition between individuals, societies and countries. This situation facilitates a want-created consumption and identity (Smith 1982). One's name, fame and 
money/wealth are key constituents of an individual's status and worth. This may become a cause of greed and violence in societies in which values and moralities are less important qualities of the human being.

The changing scenario is creating a need and demand for specialists and experts in various fields of everyday life. Event management and media based promotion are examples of an expanding area in which women/girls are gazed at by men, because men employ women's body, beauty and soft skills in these businesses.

In their jobs, women perform the duty of public care and so forth. The nature of their work and the practices standard in their professions are influential in changing their attitudes and daily behavioural habits. Thereafter, their life choices and style are reshaped and this makes them ambitious. Their lifestyle encourages a wrong understanding of justice for women and women's rights. It teaches them to compete with males. But no competition ever brings equality. In a competition only one person/side can win the race. Females are working mainly in male gazing professions and their body is used as a commodity for profit. Women's greed to enjoy name, fame and money is the cause of this new type of exploitation leading them into a new realm of male dominance. Only the merits and rational power of women can successfully save them from such male tactics. In the feminist movement and the struggle for gender justice the above aspect should be given proper importance.

\section{References}

Adkins, Lisa. 1995. Gendered Work: Sexuality, Family, and the Labour Market. Bristol: Open University Press.

Banks, Caroline Giles. 1992. "Culture in Culture Bound Syndrome: The Case of Anorexia Nervosa", Social Sciences and Medicines 34(8): 867-884 
Benet, M.K., 1972. Secretary: An Inquiry into the Female Ghetto. London: Sedgwick and Jackson.

Bordo, Susan. 1999. The Male Body. New York: Farrar, Straus, and Giroux.

Bradley, L. 1989. "Predicting learning disabilities" in Learning disabilities: Cognitive, Social and Remedial Aspects. J. J. Dumont \& H. Nakken (Eds.). Amsterdam: Swets \& Zeitlinger, pp. 1-17.

Clammer, John. 1995. "Consuming Bodies: Constructing and Representing the Female Body" in Contemporary Japanese Print Media, Woman, Media and Consumption in Japan, Lise Skov and Brian Morean (Eds.). Honolulu: University of Hawaii, pp. 197-219.

Cockburn, Cynthia. 1991. In the Way of Women: Men's Resistance to Sex Equality in Organizations. New York: ILR Press.

Crang, Philip. 1994. "It's Showtime: on the workplace geographies of display in a restaurant in Southeast England". Environment and Planning D, 12(6): 675-704.

Dotson, Edisol Wayne. 1999. Behold the Man - The Hype and Selling of Male Beauty in Media and Culture. Binghamton, NY: Haworth Press.

Engels, Friedrich. 1948 (1884). The Origin of the Family, Private Property and the State, Moscow: Progress Publishers.

Fine, G. 1996. "Justifying work: occupational rhetoric in restaurant kitchens". Administrative Science Quarterly, 41(1): 90-112.

Fromm, Erich. 1955. The Sane Society. New York: Holt, Rinehart, \&Winston.

Furman, Frida Kerner. 1997. Facing the Mirror: Older Women and Beauty Shop Culture. New York: Routledge.

Geetha, V. 2002. Gender. Kolkata: Stree.

Gherardi, Susan. 1995. Gender, Symbolism and Organisation's Culture. London: Sage.

Giddens, Anthony. 1992. The Transformation of Intimacy. Stanford, CA: Stanford University Press.

Gimblin, Debra. 1996. "Pamela's Place: Power and Negotiation in the Hair Salon”. Gender and Society, 10(4): 505-26.

Hakim, Catherine. 2010. "Erotic Capital”, European Sociological Review, 26(6): 499-518.

Hall, E.J. 1993. "Waitering/waitressing: Engendering the Work of Table Servers". Gender and Society, 17: 329-46. 
Harvey, P. 2013. "Buddhist Reflections on "Consumer" and "Consumption”, Journal of Buddhist Ethics, 20: 334-356.

Hochschild, Arlie Russell. 1983. The Managed Heart. Berkeley, CA: University of California Press.

James, Nicky. 1989. "Emotional Labour: Skill and Work in the Social Regulation of Feelings". Sociological Review, 37(1): 15-42.

McDowell, Linda. 1997. Capital Culture: Gender at Work in the City. Oxford: Blackwell.

National Geographic News, 2013. http://www.news.nationalgeographic.com/news/pf/55932035.htm

Niranjana, T. and Vasudevan, N. 2016. "Cultural Lives of Young Women in Globalizing India: Reorganization of Desire”, Economic and Political Weekly, 51(14)

O’Brien, Martin. 1994. "The Managed Heart Revisited: Health and Social Control". Sociological Review, 42(4): 393-413.

Oerton, Sarah and Phoenix, James. 2001. "Sex/Bodywork: Discourses and Practices". Sexualities, 4(4): 387-412.

Orbach, Susie. 2005. Hunger Strike: The Anorectic's Struggle as a Metaphor for our Age. USA: Karnac Books.

O'Toole, L. 2003. The Case of Massage Therapy. Gender, Work and Organization Conference, UK: Keele University.

Prince, Raymond. 1985. "The Concept of Culture Bound Syndrome: Anorexia Nervosa and Brain Fag”, Social Science and Medicine, 21(2): 197-203.

Pringle, Rosemary. 1988. Secretaries Talk. London: Verso.

Rees, T. 1992. Women and the Labour Market. London: Routledge.

Rich, Adrienne. 1996. Of Woman Born: Motherhood as Experience and Institution. USA: W.W Norton \& Company

Sen, Amartya. 1999, Development as Freedom, Oxford: Oxford University Press

Sharma, U and Black, P. 2001, "Look Good, Feel Better: Beauty Therapy as Emotional Labour", Sociology, 35: 913-931

Smith, Adam. 1982 (1790). The Theory of Moral Sentiments. Indianapolis: Liberty Fund.

Tennov, Dorothy. 1979. Love and Limerence: The Experience of Being in Love. New York: Stein and Day. 